\title{
Examination of Sodium Titanate Applicability in the In-Tank Precipitation Process
}

by

D. J. McCabe

Westinghouse Savannah River Company

Savannah River Site

Aiken, South Carolina 29808

This paper was prepared in connection with work done under the above contract number with the U.S.

Department of Energy. By acceptance of this paper, the publisher and/or recipient acknowledges the U. S. Government's right to retain a nonexclusive, royalty-free license in and to any copyright covering this paper, along with the right to reproduce and to authorize others to reproduce all or part of the copyrighted paper. 


\section{DISCLAIMER}

This report was prepared as an account of work sponsored by an agency of the United States Government. Neither the United States Government nor any agency thereof, nor any of their employees, makes any warranty, express or implied, or assumes any legal liability or responsibility for the accuracy, completeness, or usefulness of any information, apparatus, product, or process disclosed, or represents that its use would not infringe privately owned rights. Reference herein to any specific commercial product, process, or service by trade name, trademark, manufacturer, or otherwise does not necessarily constitute or imply its endorsement, recommendation, or favoring by the United States Government or any agency thereof. The views and opinions of authors expressed herein do not necessarily state or reflect those of the United States Government or any agency thereof.

This report has been reproduced directly from the best available copy.

Available to DOE and DOE contractors from the Office of Scientific and Technical Information, P. O. Box 62, Oak Ridge, TN 37831; prices available from (423) 576-8401.

Available to the public from the National Technical Information Service, U. S. Department of Commerce, 5285 Port Royal Road, Springfield, VA 22161. 


\section{DISCLAIMER}

Portions of this document may be illegible electronic image products. Images are produced from the best available original document. 
WSRC-TR-97-0015

Revision 0

Keywords : In-Tank

Precipitation, Sodium

Titanate

Retention: Permanent

Examination of sodium Titanate Applicability in the InTank Precipitation Process (U)

April 25, 1997

D.J. McCabe, 773-43A

B.W. Walker, 676-T

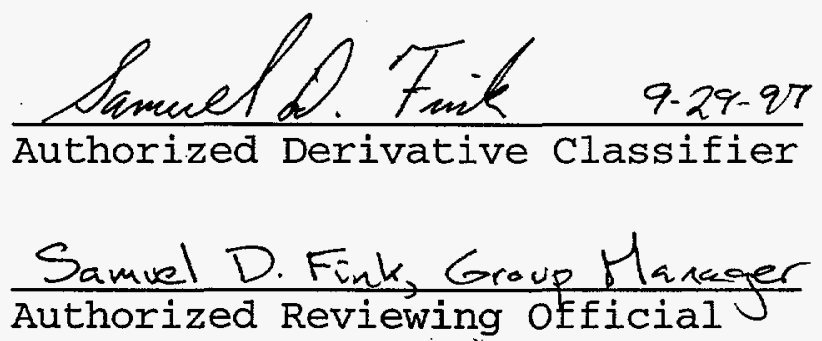

Savannah River Technology Center

Westinghouse Savannah River Company

Aiken, SC 29808

Prepared for the Department of Energy, Office of Science and Technology, Technical Task Plan SR1-3-20-07 
WSRC-TR-97-0015

Revision 0

\section{Summary}

The In-Tank Precipitation (ITP) process decontaminates radioactive waste by precipitating radioactive cesium with tetraphenylborate ( TPB $^{-}$) and adsorbing strontium and actinides on monosodium titanate (MST). An alternative strontium absorbent material, sodium titanate (ST), has been developed by AlliedSignal, Inc. as part of the Efficient Separations and Processing Crosscutting Program of the Department of Energy Office of Science and Technology. An examination using simulated and radioactive waste indicates this material is effective for Savannah River Site High Level Waste (HLW), although the particle size of the material must be optimized to reduce the impact on filtration. The highest average decontamination factors after 48 hours was 260 ( \pm 100 ). This performance is higher than the specified decontamination factor of 150 for MST used in ITP. Progress has been made by the vendor in formulating improvements in the material since the preliminary examination of this material. ${ }^{1}$

The Alliedsignal material is being examined because of three potential benefits over the conventional MST:

- potential for higher ITP filter performance due to a larger particle size while retaining decontamination effectiveness,

- absence of residual alcohols in the material, and

- potential for increasing the ratio of plutonium to uranium selectivity, thereby reducing the alpha-emitting radionuclide content in Saltstone.

This study concluded that, compared to MST, the Alliedsignal material:

- exhibits a higher Sr decontamination factor

- has similar Pu and U loading

- produces a 35\% decrease in filter flux, relative to MST

- has no negative influence on chemical cleaning of the Mott filters

\section{Introduction}

The ITP Process decontaminates radioactive waste in Tank $48 \mathrm{H}$ by precipitating cesium with $\mathrm{TPB}^{-}$and adsorbing strontium on MST. The radioactive solids are separated from the salt solution by cross flow filters. Alternate strontium sorbents are being examined due to several factors. Principal among these are the potential for increased filter performance and improved selectivity of plutonium to uranium absorption. Increasing the plutonium absorption and decreasing the uranium absorption would reduce the alpha-emitting radionuclide (primarily $\mathrm{Pu}$ and $\mathrm{Np}$ ) content in the treated waste while using the same amount of ion exchange material. The limit on alpha-emitting radionuclides in treated material is based on the Waste Acceptance Criteria for the Saltstone facility at SRS. 
The supplier of material tested in this study, sodium titanate (ST), is AlliedSignal, Inc. The materials are reported by the vendor to be within the current particle size specification for MST (<1 wt \& less than 1 micron, $<1$ wt \& greater than 35.5 microns). ${ }^{2}$

These tests allow determination of the decontamination factor (DF) for any radionuclide:

$$
\mathrm{DF}=[\mathrm{C}]_{i} /[\mathrm{C}]_{\mathbf{f}}
$$

where $[\mathrm{C}]_{i}=$ initial radionuclide concentration and $[\mathrm{C}]_{f}=$ final concentration.

Prior to proposing use of this compound as a replacement for MST, the compatibility and effectiveness of it must be examined. Comparisons of the absorption of uranium, plutonium, neptunium, americium, and curium are also needed if the absorption of strontium proves effective.

The development of this material was funded by the Department of Energy, Office of Science and Technology, Efficient Separations and Processing Crosscutting Program. Testing of this material at SRS was also funded by the Efficient Separations and Processing Crosscutting Program (Technical Task Plan SR1-3-20-07); John Mathur, DOE Headquarters Program Manager.

\section{Experimental}

\section{Standard Decontamination Factor Measurements}

Three replicate salt solution samples were prepared for each sample of ST received from AlliedSignal (lot numbers: 8212-79, 8212-89-1, 8212-91, 8212-123, and 8212-107 [slurry of 8212-89-1]). The standard simulant salt solutions (SSS-95-3 or SSS-96-1, Table 1) were prepared from reagent grade chemicals.

The salt solutions remained slightly turbid after 12 hours and were filtered to remove any insoluble solids. The solid (or slurry) samples of ST $(\sim 50 \mathrm{mg})$ were contacted with $100 \mathrm{~mL}$ of the filtered simulated salt solution. The mixtures of salt solution and ST were stirred at room temperature $\left(\sim 23^{\circ} \mathrm{C}\right)$. Contact time for these measurements was 48 hours. After the contact time elapsed, the samples were then filtered through a 0.2 micron Nalgene disposable filter apparatus and analyzed by gamma counting for Sr-85. Blank solutions were also filtered through an identical filter and the filtrate analyzed. 
Table 1. 5.2 M [Na+] Standard Simulated Aqueous Salt Solution

\begin{tabular}{lc} 
Component & Concentration (M) \\
\hline $\mathrm{Na}_{2} \mathrm{SO}_{4}$ & 0.14 \\
$\mathrm{NaNO}_{2}$ & 0.73 \\
$\mathrm{NaNO}_{3}$ & 1.07 \\
$\mathrm{NaOH}$ & 2.66 \\
$\mathrm{NaCl}$ & 0.022 \\
$\mathrm{NaF}$ & 0.015 \\
$\mathrm{Na}_{2} \mathrm{SiO}_{3} \cdot 9 \mathrm{H}_{2} \mathrm{O}$ & 0.0039 \\
$\mathrm{Na}_{3} \mathrm{PO}_{4} \cdot 12 \mathrm{H}_{2} \mathrm{O}$ & 0.0083 \\
$\mathrm{Na}_{2} \mathrm{CO}_{3} \cdot \mathrm{H}_{2} \mathrm{O}$ & 0.17 \\
$\mathrm{Al}\left(\mathrm{NO}_{3}\right)_{3} \cdot 9 \mathrm{H}_{2} \mathrm{O}$ & 0.31 \\
$\mathrm{Na} \mathrm{C}_{2} \mathrm{O}_{4}$ & 0.014 \\
$\mathrm{Sr}(\mathrm{non}$-rad.) & $<0.18 \mathrm{mg} / \mathrm{L}$ \\
$\mathrm{Sr}-85$ & $0.06 \mathrm{mCi} / \mathrm{L}$
\end{tabular}

\section{Actinide Loading Measurements}

A simulated salt solution ${ }^{3}$ (4.27 $\mathrm{M} \mathrm{Na}^{+}$, Table 2) was spiked with Sr-85, commercial depleted uranyl nitrate hexahydrate

(Mallinckrodt, lot $8640,200 \mathrm{~g} / \mathrm{L} \mathrm{U}$ solution), and weapons grade plutonium (Kyser CR\#99, $30.7 \mathrm{~g} / \mathrm{L} \mathrm{Pu}-239$ ). The ratio of ST to salt solution varied from 0.9 to $0.05 \mathrm{~g} / \mathrm{L}$. Three replicate salt solution samples were prepared for each concentration of ST. The ST was from samples obtained from AlliedSignal (lot numbers: 821289-1, 8212-123) and Boulder Scientific (BSC2650005). The 4.27 M $\mathrm{Na}^{+}$simulant salt solutions (Table 2) were prepared from reagent grade chemicals.

Table 2. $4.27 \mathrm{M}[\mathrm{Na}+]$ Simulated Aqueous Salt Solution for Actinide Loading Studies

\begin{tabular}{lc} 
Component & Concentration (M) \\
\hline $\mathrm{SO}_{4}{ }^{-}$ & 0.40 \\
$\mathrm{NO}_{2}{ }^{-}$ & 0.10 \\
$\mathrm{NO}_{3}{ }^{-}$ & 1.00 \\
$\mathrm{OH}^{-}$ & 2.00 \\
$\mathrm{CO}_{3}{ }^{-}$ & 0.02 \\
$\mathrm{AlO}_{2}^{-}$ & 0.33 \\
$\mathrm{U}^{-} 238$ & $10.6 \mathrm{mg} / \mathrm{L}$ \\
$\mathrm{Pu}-239$ & $0.150 \mathrm{mg} / \mathrm{L}$
\end{tabular}

The salt solution was spiked with non-radioactive strontium, filtered, Sr-85 added, filtered, uranium and plutonium added, stirred for 5 days, and filtered. The mixtures of salt solution and ST were stirred at room temperature $\left(\sim 23^{\circ} \mathrm{C}\right)$. Contact time for these measurements was 48 hours. After the contact time elapsed, the samples were filtered through a 0.2 micron Nalgene® disposable filter apparatus and analyzed by gamma counting for Sr- 
WSRC-TR-97-0015

Revision 0

85, and by Inductively Coupled Plasma - Mass Spectroscopy (ICP-MS) for actinides. Blank solutions (no ST) were also filtered through an identical filter and the filtrate analyzed.

\section{Radioactive Waste Decontamination Factor Measurements}

Radioactive waste salt solution samples were received from Tanks $43 \mathrm{H}(7 / 94)$ and $46 \mathrm{H}(8 / 94)$ and adjusted to a density of $1.24 \mathrm{~g} / \mathrm{mI}$ with deionized water. The samples were stirred for over 10 hours at room temperature, and filtered with a 0.2 micron Nalgene@ filter. The ST ( 10 mg, lot \#8212-89-1) was mixed with a $20 \mathrm{~mL}$ aliquot of the salt solution, and the slurry stirred at room temperature $\left(\sim 25^{\circ} \mathrm{C}\right)$ for 48 hours. The samples were then filtered with a 0.2 micron Nalgene® filter. The samples were next acidified by mixing with an equal volume of $8 \mathrm{M}$ nitric acid and mixed with Bio-Rad AMP-1 resin $(0.1 \mathrm{~g} / \mathrm{mL})$ to remove radioactive cesium. The resin was then removed by filtration ( 0.45 micron) and washed with water. The aqueous samples were then analyzed. The initial untreated sample was also acidified and treated with AMP-1 resin prior to analysis. An initial untreated sample was also diluted ( 1000:1) with deionized water and analyzed. The samples were analyzed by counting the radioactive Sr-90 and Sr-85 decay energy, and by measuring the Sr-88 and actinide concentrations using ICP-MS.

Simulated Tanks $43 \mathrm{H}$ and $46 \mathrm{~F}$ Waste Decontamination Factor Measurements

Simulants designed to mimic the major constituents in the Tank $43 \mathrm{H}$ and Tank 46F samples were prepared from reagent grade chemicals (Table 3). These simulants were spiked with Sr-85.

Decontamination factor experiments, identical to those described above for standard salt solution, were performed with Alliedsignal ST (lot \#8212-89-1).

Table 3. Simulated Tank $43 \mathrm{H}$ and $46 \mathrm{~F}$ Salt Solutions

\begin{tabular}{|c|c|c|}
\hline \multirow[b]{2}{*}{ Component } & \multicolumn{2}{|c|}{ Concentration (M) } \\
\hline & Tank $43 \mathrm{H}$ & Tank 46F \\
\hline $\mathrm{Na}^{+}$ & 7.46 & 7.63 \\
\hline $\mathrm{NO}_{2}-$ & $\begin{array}{l}0.13 \\
0.87\end{array}$ & $\begin{array}{l}0.40 \\
1.87\end{array}$ \\
\hline $\begin{array}{l}\mathrm{OH}^{-} \\
\mathrm{AlO}_{2}^{-}\end{array}$ & $\begin{array}{l}6.03 \\
0.27\end{array}$ & $\begin{array}{l}5.5 \\
0.23\end{array}$ \\
\hline
\end{tabular}

In-Tank Precipitation Simulant Filter Performance

A sample of AlliedSignal ST (lot \#8212-123) was mixed with a simulated ITP slurry of potassium tetraphenylborate and salt solution. The formulation for the 1 wt 8 insoluble solids simulant has been described. ${ }^{4}$ A sample of MST (Optima Drum \#4) was mixed with a second sample of simulated ITP slurry. Both samples 
used a final ST (or MST) concentration of $0.21 \mathrm{~g} / \mathrm{L}$. The slurries were then tested using the Parallel Rheology Experimental Filter (PREF). The PREF was equipped with 0.5 micron Mott sintered-metal filters. The tests used a standard statistically designed test matrix. ${ }^{4}$ At the conclusion of each experiment, the filters were chemically cleaned with 2.0 wt of oxalic acid for 1 hour. To verify that the filter was clean, the filtrate flow rate with deionized water was determined. In both cases, the filtrate clean water flux was restored after the chemical cleaning.

Particle size distribution data were collected on the Alliedsignal ST sample (lot \#8212-123). The sample was analyzed using a Microtrac II, Series 7998 Particle Size Analyzer. The range of this instrument is 0.7 to 700 microns. The instrument operates via low-angle forward scattering of diode laser light.

\section{Results and Discussion}

\section{Standard Decontamination Factor Measurements}

The calculated decontamination factors (DFs) for the samples of ST are presented in Table 4 as corrected for slight changes in the weight of ST used in each experiment. The variability in the DF was calculated by a propagation of errors. The reported variability is the $95 \%$ confidence interval for the measurement.

Table 4. Standard DF measurements

$\begin{array}{lcl}\text { Lot \# } & \mathrm{DF}(48 \text { hour }) & \mathrm{Kd}(\mathrm{mL} / \mathrm{g}) \\ 8212-79^{1} & 47 \pm 22 & 9.2 \mathrm{E} 4 \\ 8212-89-1^{1} & 73 \pm 24 & 1.4 \mathrm{E} 5 \\ 8212-107 & 69 \pm 16 & 1.4 \mathrm{E} 5 \\ 8212-91^{1} & 101 \pm 26 & 2.0 \mathrm{E} 5 \\ 8212-123 & 260 \pm 100 & 5.2 \mathrm{E} 5\end{array}$

During the test program, Alliedsignal improved the formulation of the material to increase the strontium absorption. The results in Table 4 are in chronological order of manufacture. The efforts to improve the strontium absorption capacity have been highly successful. The characteristic that causes the difference between these samples is not known to SRTC personnel due to proprietary concerns. All samples were reported by the vendor to be within the particle size specification for MST.

\section{Actinide Loading Measurements}

The best available (at the time of the experiment) Alliedsignal material (8212-89-1) was used in actinide loading experiments to evaluate the absorption of uranium and plutonium. A sample of 8212-123 was also included in the study when it became available. Comparison tests were completed using a sample of the Boulder 
Scientific Co. (BSC2650005) manufactured material. This material was used by D.T. Hobbs in earlier actinide loading experiments. ${ }^{6}$

Table 5. Actinide Simulant Measurements

\begin{tabular}{|c|c|c|c|c|}
\hline Lot \# & Loading & Dec & $\begin{array}{l}\text { ination } \\
\mathrm{U}\end{array}$ & $\mathrm{Pu}$ \\
\hline $8212-89-1$ & $0.053 \mathrm{~g} / \mathrm{L}$ & $3.8 \pm 1.4$ & $0.98 \pm 0.05$ & $\frac{1.64 \pm 0.58}{3}$ \\
\hline$"$ & $\begin{array}{l}0.17 \\
0.31\end{array}$ & $\begin{array}{l}30 \pm 6.8 \\
97 \pm 10\end{array}$ & $\begin{array}{l}1.03 * \\
1.02 \pm 0.06\end{array}$ & $\begin{array}{l}3.43^{*} \\
5.45^{2}+1.97\end{array}$ \\
\hline$"$ & 0.89 & $720 \pm 293$ & $1.20 \pm 0.07$ & $12.8 \pm 7.2$ \\
\hline $8212-123$ & 0.30 & $231 \pm 116$ & $1.25 \pm 0.14$ & $24.3 \pm 15$. \\
\hline BSC "standard" & 0.30 & $84 \pm 11$ & $1.18 \pm 0.05$ & $24.9 \pm 19$. \\
\hline
\end{tabular}

* only two samples used for DF determination due to apparent analytical problems

The results indicate that the decontamination factors of plutonium are lower with 8212-89-1 AlliedSignal material than with the BSC material, although uncertainty in the plutonium absorption is large for the BSC material. The uranium decontamination factor is also marginally lower for this material. The actinide absorption of the AlliedSignal 8212-123 material is comparable to that for the BSC material. The strontium decontamination factor for the BSC material is much higher than previously reported for solutions doped with strontium, uranium, and plutonium, but this may result from the lower sodium concentration in this simulant. Overall, the 8212-123 material shows good removal of Sr, U, and Pu.

The loading of $\mathrm{Pu}$ observed by $\mathrm{Hobbs}^{6}$ for the BSC material at 0.066 wt $8 \mathrm{Pu}$ (calculated) at $0.3 \mathrm{~g} / \mathrm{L}$ MST was higher than that observed here (Table 6). However, this work indicates that the 8212-123 material is comparable to the BSC material, and the 8212-89-1 is only slightly lower. The plutonium loading for the three materials tested are shown in Figure 1 . The curve for the 821289-1 material appears logarithmic, as opposed to the previous work which indicated linear behavior. ${ }^{6}$ The plutonium loading is comparable to that previously observed.

Table 6. Actinide Simulant Loading Calculations

\begin{tabular}{llll} 
Lot \# & Loading & wt $8 \mathrm{U}$ & wt $8 \mathrm{Pu}$ \\
\hline $8212-89-1$ & $0.053 \mathrm{~g} / \mathrm{L}$ & $<\mathrm{d} .1$. & 0.123 \\
" & 0.17 & $0.36^{\star}$ & $0.063^{\star}$ \\
" & 0.31 & 0.17 & 0.039 \\
" & 0.89 & 0.23 & 0.015 \\
$8212-123$ & 0.30 & 0.788 & 0.047 \\
BSC "standard" & 0.30 & 0.62 & 0.047
\end{tabular}

$<$ d.1. = less than detection limit

* only two samples used for DF determination due to apparent analytical problems 


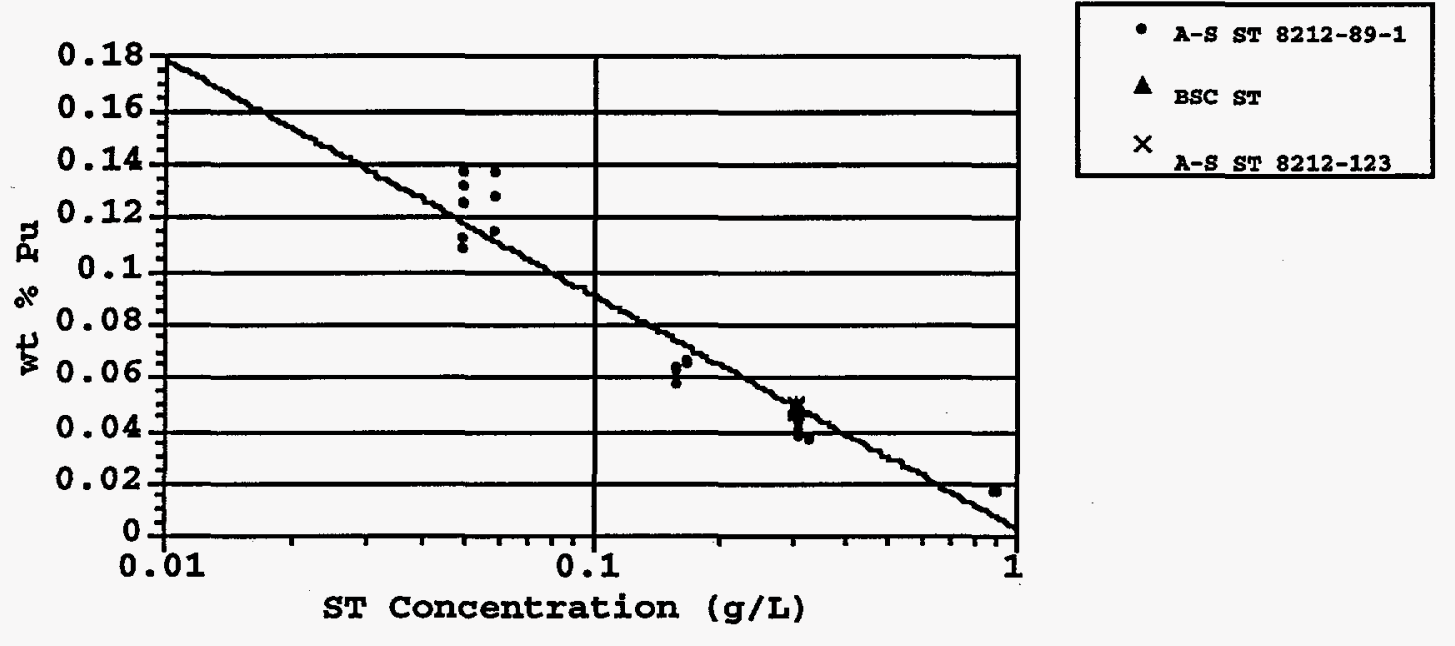

Figure 1. Plutonium loading on sodium titanates

wt $\% \mathrm{Pu}=-3.825700 \mathrm{E}-2$ * $\ln (\mathrm{ST}$ concentration $)+3.002941 \mathrm{E}-3$ $\mathrm{R}^{2}=9.357302 \mathrm{E}-1$

The uranium loading in the previous work ${ }^{6}$ was 0.64 wt o $\mathrm{U}$ (calculated) at $0.3 \mathrm{~g} / \mathrm{L}$ MST. This loading exceeds that for the 8212-89-1 material, but is lower than the 8212-123 material. The BSC and 8212-123 materials both had higher uranium loading than the 8212-89-1 material. The uranium loading for all three materials is shown in Figure 2. Results from several tests with the 8212-89-1 material, primarily at 0.05 $\mathrm{g} / \mathrm{L} \mathrm{ST}$, were deleted from Figure 2. The deletions were necessary because the differences between initial and final uranium concentrations were within the scatter of the data and the calculated decontamination factors were less than unity. These are shown in Table 6 as less than the detection limit. The loading of uranium vs. ST concentration (Figure 2) appears linear, although the data is scattered. The linear behavior of uranium loading agrees with previous work with MST manufactured by Boulder Scientific. 

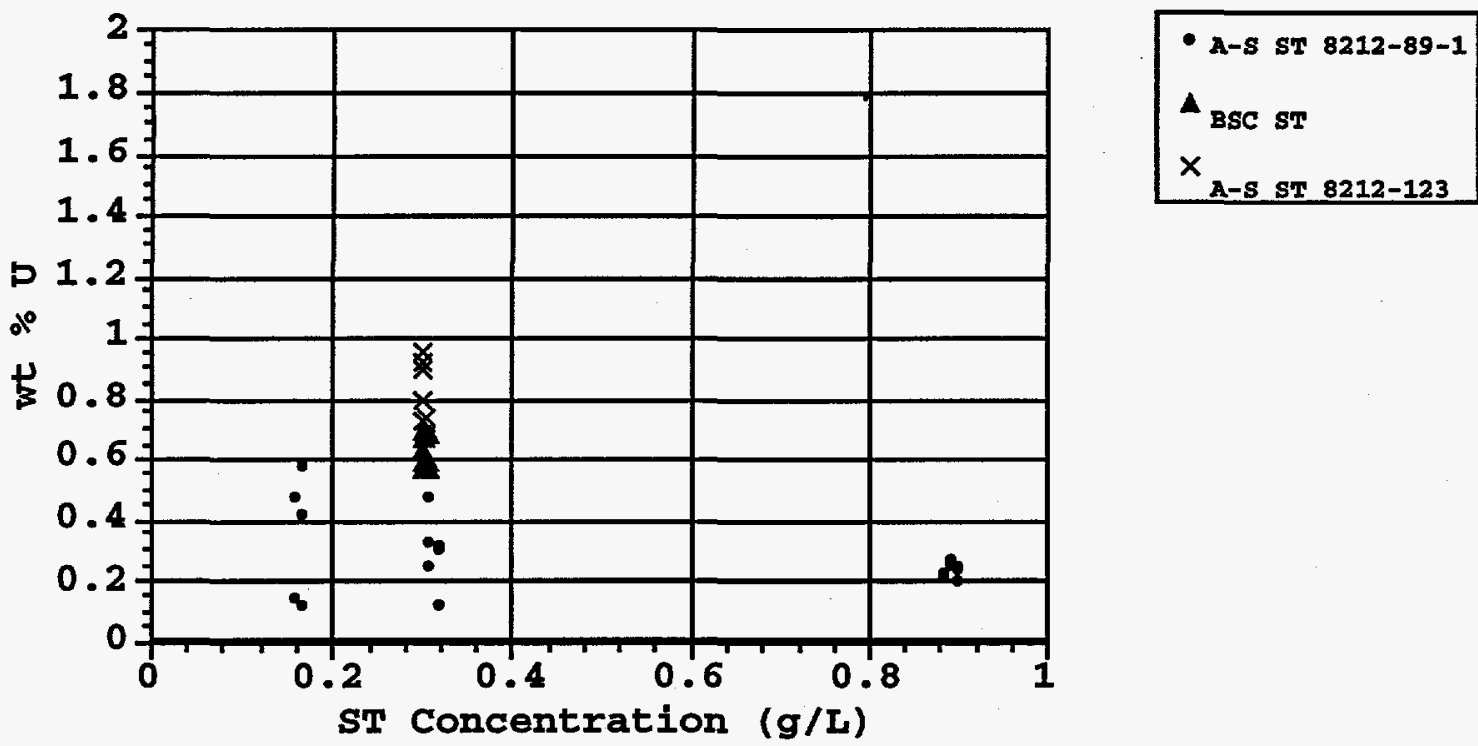

Figure 2. Uranium Loading on Sodium Titanates

\section{Radioactive Waste Decontamination Factor Measurements}

Radioactive waste samples were used in standard decontamination factor tests in the SRTC Shielded Cells. The results (Table 7) indicate that strontium removal was not very effective. Also, the removal of actinides proved inconsistent. The U-235 analysis indicated more uranium in the treated sample than in the untreated sample (i.e., DF $<1$ ). These observations were attributed to cross contamination of samples or contamination from the Shielded Cells environment.

Table 7. Standard DF measurements with Radioactive Waste Samples

\begin{tabular}{lcc} 
Radionuclide & DF Tank $43 \mathrm{H}$ & DF Tank $46 \mathrm{~F}$ \\
\hline Sr-90 & $<1^{*}$ & $1.6^{*}$ \\
Sr-88 & 3.4 & 1.9 \\
Th-230 & n.d. & $>11$ \\
U-235 & 1.4 & 0.6 \\
Np-237 & 2.8 & $>20$ \\
Pu-239 & 3.6 & 1.6 \\
Am-243 & n.d. & $>11$ \\
$\mathrm{Cm}-245$ & $>36$ & n.d.
\end{tabular}

* significant interference from $\mathrm{H}-3$ or $\mathrm{Ru}-106$ $\mathrm{n} . \mathrm{d}$. = none detected

To further evaluate the possibility that the samples were contaminated through manipulation in the shielded cells or that interference from other radionuclides was impeding the analysis, 
the samples from Tanks $43 \mathrm{H}$ and $46 \mathrm{~F}$ were reused in a decontamination factor test. The samples were spiked with Sr-85 to allow comparison of $\mathrm{Sr}-85$ with $\mathrm{Sr}-90$ analyses. Replicate tests were not feasible due to the lack of sample volume.

Table 8. Standard DF Measurements with Reused Radioactive Waste Samples

\begin{tabular}{lll} 
Lot \# & DF Tank $43 \mathrm{H}$ & DF Tank $46 \mathrm{~F}$ \\
\hline Sr-85 & $5.1^{*}$ & $\mathrm{n} . \mathrm{d}$. \\
$\mathrm{Sr}-90$ & $39^{*}$ & $<1$ \\
$\mathrm{U}-234$ & 3.4 & $\mathrm{n} . \mathrm{d}$.
\end{tabular}

*significant interference from $\mathrm{Ru}-106$

n.d. = not detected

The initial Sr-90 concentration in the Tank $43 \mathrm{H}$ sample was only slightly above the Saltstone Waste Acceptance criteria 10.04 $\mathrm{uCi} / \mathrm{g}$ ) and the initial Tank $46 \mathrm{~F}$ sample is below the limit. The transuranic actinides were removed in the first decontamination test, and were below the detection limit after the second. The analyses of the U-234 isotope was in the proximity of the detection limits for the ICP-MS analyses, reducing the confidence in the analyses. The Sr-88 analyses indicated that the concentration of strontium was also near the detection limit. A significant interference from Ru-106 was noted in the $\mathrm{Sr}-90$ and Sr-85 analyses. These data suggest that the widely varying results are due to scatter in the data near the detection limit. Use of samples containing higher initial concentrations of Sr-90 are recommended for further testing. The poor decontamination factors observed in the radioactive samples are probably not due to an attribute of the AlliedSignal material.

Simulated Tanks $43 \mathrm{H}$ and $46 \mathrm{~F}$ Waste Decontamination Factor Measurements

Simulants were prepared that contained the major constituents of the Tank $43 \mathrm{H}$ and $46 \mathrm{~F}$ waste. The solutions were spiked with Sr-85, and comparison tests were performed (Table 9) with the same batch of ST as the radioactive waste tests (AS 8212-89-1). Although the results indicate lower decontamination factors when compared with standard salt solution, the higher sodium concentration of these simulants is expected to reduce strontium removal. ${ }^{3}$

Table 9. Simulated Tank $43 \mathrm{H}$ and $46 \mathrm{~F}$ Sr-85 Decontamination Factor Measurements

$\begin{array}{ll}\text { Simulant } & \text { Sr-85 DF } \\ \text { Tank 43H } & 39 \pm 8 \\ \text { Tank 46F } & 54 \pm 12\end{array}$




\section{In-Tank Precipitation Simulant Filter Performance}

The performance of the filters with Optima MST and AlliedSignal ST are statistically different. The filter performance can be described by the following equation:

$Q=0.0489+0.0011 d P+0.0093 \mathrm{~V}+0.0444 f($ type $)$

Where $Q=$ the filtrate $f l u x$ in gpm/ft ${ }^{2}$, dP is the differential pressure (transmembrane) in psi, $V$ is the axial velocity in gpm, and $f=1$ for Optima MST and $f=0$ for Alliedsignal ST.

The Optima MST filtrate flux (Figure 3) is approximately 35\% higher than the AlliedSignal material (8212-123). The difference in performance is likely due to the difference in particle size of the two materials. The average particle size of the Alliedsignal ST was 3.10 microns, and the optima material was 17.2 microns. The AlliedSignal material has a much narrower size distribution of particles than the Optima material. Both materials exceeded the acceptance criteria for fines ( $<1$ vol \& less than 1 micron), with the Alliedsignal material at 3 vol $\%$ and the Optima material at 1.5 vol \% less than 1 micron. The Optima material also exceeded the criteria for large particles with 20 vol \% greater than 35.5 microns. Routine chemical cleaning with oxalic acid and sodium hydroxide was adequate to restore the filter to pristine conditions, based on the clean water flux.

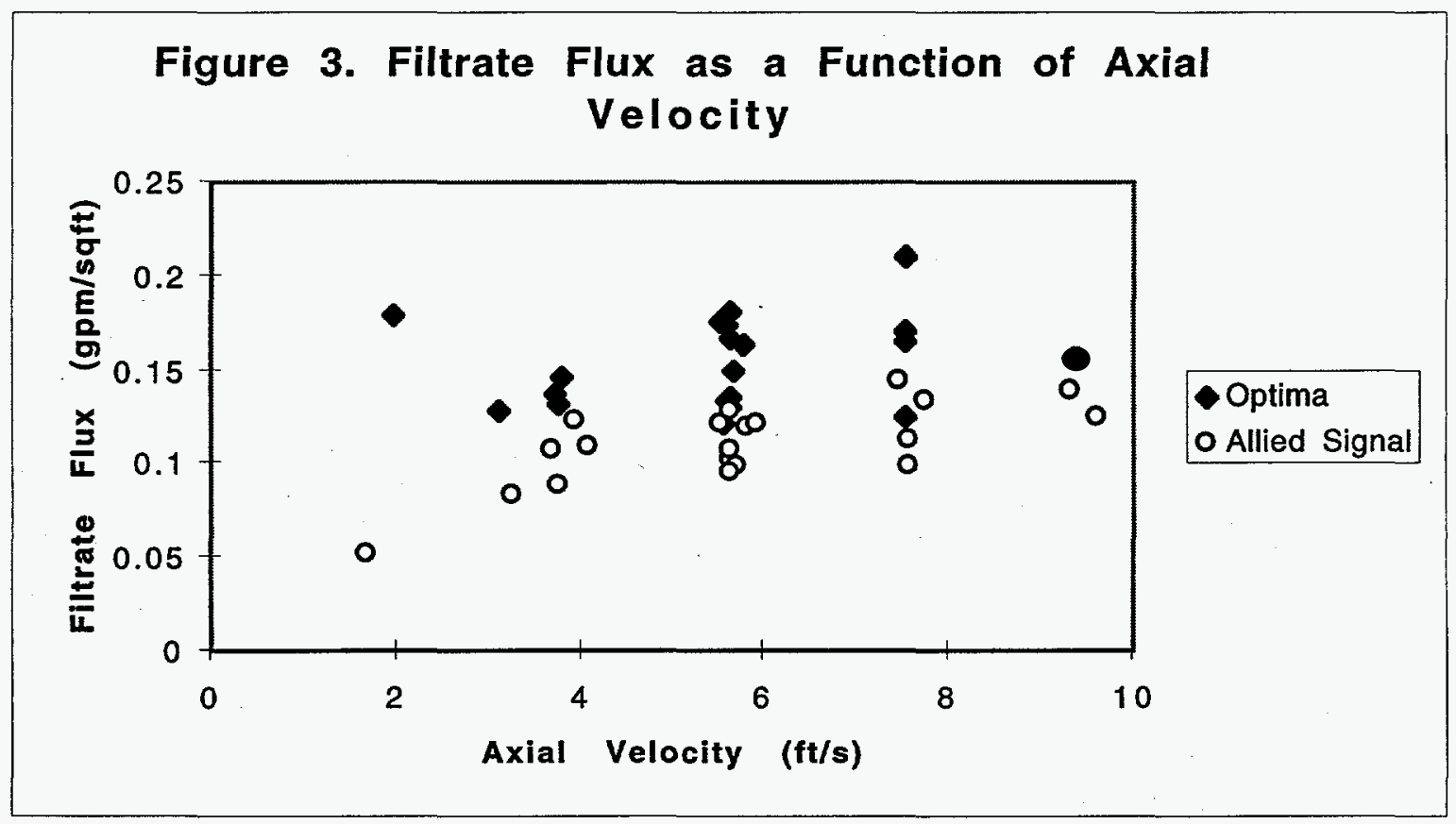




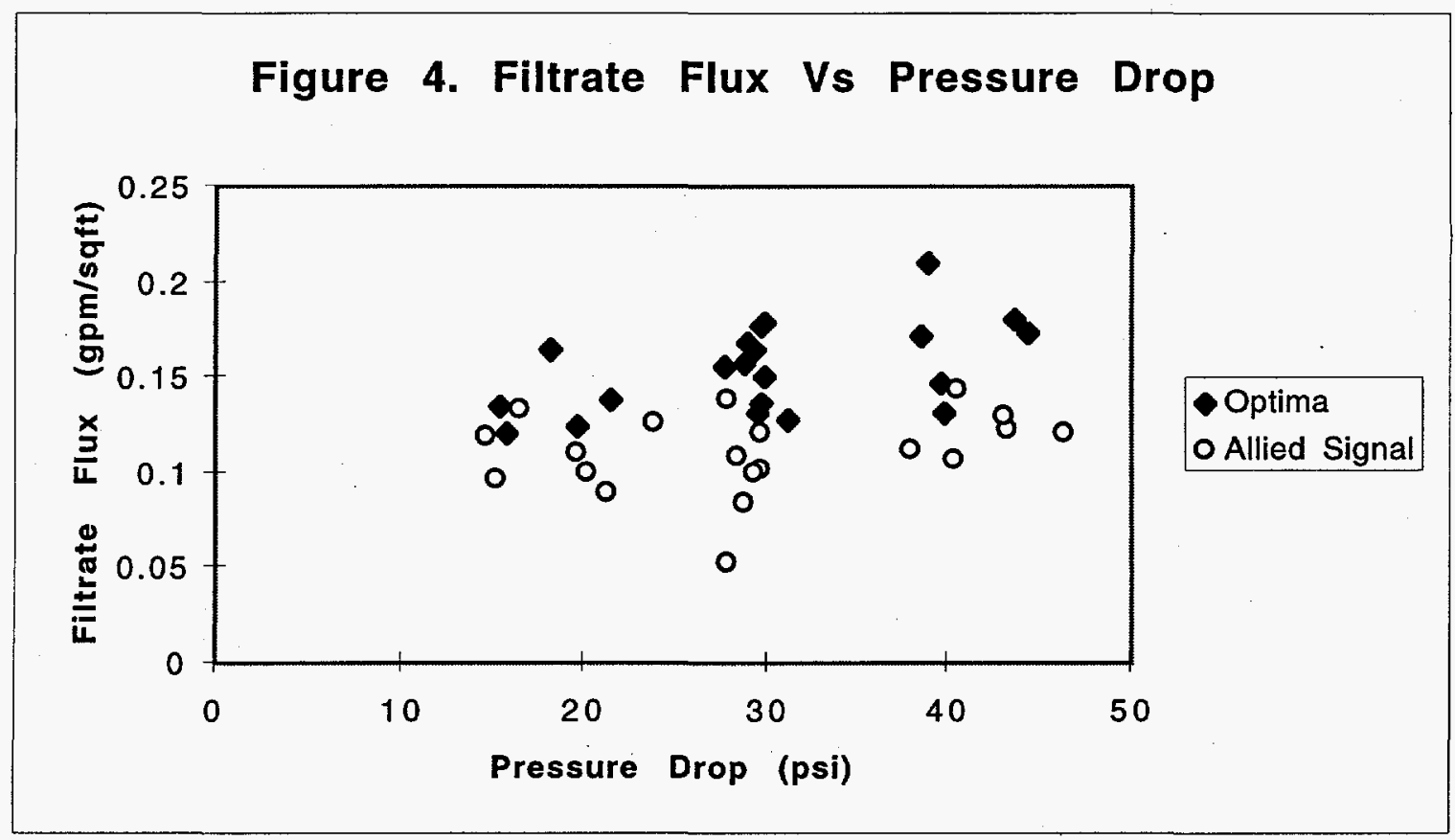

\section{Conclusions}

The AlliedSignal sodium titanate material requires only slight modifications to be acceptable for use in ITP. Increasing the particle size is necessary to avoid impacting the filter performance. Increasing the particle size will decrease the surface area and is expected to decrease the strontium decontamination factor. Although the decontamination factor will be impacted, the newest formulation (8212-123) exceeds the acceptance criteria for strontium removal. The particle size and decontamination factor will need to be balanced to optimize performance of both the filter and the strontium removal.

The removal of strontium from radioactive samples was not clearly demonstrated due to experimental design limitations. The analytical results were not internally consistent, suggesting an interference in the counting method. The decontamination performance for simulated waste was relatively well behaved and consistent with previous results using ST from other vendors.

\section{References}

1. D.J. MCCabe, "Sodium Titanate Preliminary Examination Results (U) ", WSRC-TR-95-0341, August 14, 1995.

2. Procurement Specification for Monosodium Titanate, Z-SPP-H00001 , Rev. 2, J.B. Harris, May 1, 1992. 
3. Hobbs, D.T., and Walker, D.D., "Plutonium and Uranium Adsorption on Monosodium Titanate (U)", WSRC-RP-92-93, August 13, 1992 .

4. Peterson, R.A., Nash, C.A., McCabe, D.J., "Influence of Particulates on Crossflow Filter Performance with

Tetraphenylborate Precipitate", WSRC-MS-95-0370, August 30, 1995.

5. Hobbs, D.T., "In-Tank Precipitation: Effect of Concentration, Temperature, and Reagent Addition Order on the Cesium-137 and Strontium-85 Decontamination Factor", DPST-85-420, April 9, 1985.

6. Hobbs, D.T., "Fissile Solubility and Monosodium Titanate Loading Tests (U)", WSRC-RP-92-1273, February 12, 1993.

\section{Acknowledgments}

Sodium titanate was provided by Steve Yates of AlliedSignal, Inc. This work was funded by the Department of Energy, Office of Science and Technology, through the Efficient Separations and Processing Crosscutting Program, John Mathur, Headquarters Program Manager.

Design Check

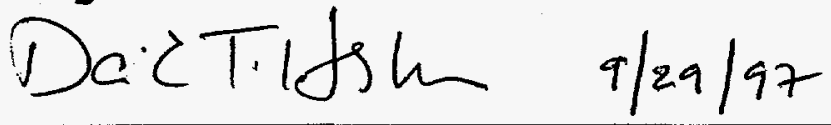

D.T. Hobbs, Waste Processing Technology date 


\section{Distribution:}

W.L. Tamosaitis, 773-A

D.T. Hobbs, 773-A

A.W. Wiggins, 241-152H

M.C. Thompson, 773-A

M.G. Schwenker, 703-46A

J.E. Marra, 704-T

M.D. Johnson, 704-56H

D.D. Walker, 773-A

L.N. Oji, 773-43A

W.L. Kuhn, PNL

J. Mathur, DOE

J.S. Watson, ORNL

J.N. Brooke, 773-A

N.R. Davis, 719-4A

B.L. Lewis, 703-H

S.F. Yates, AlliedSignal, Inc.

Tech. Info. Mgmt, 703-43A

IWT file, 773-A 